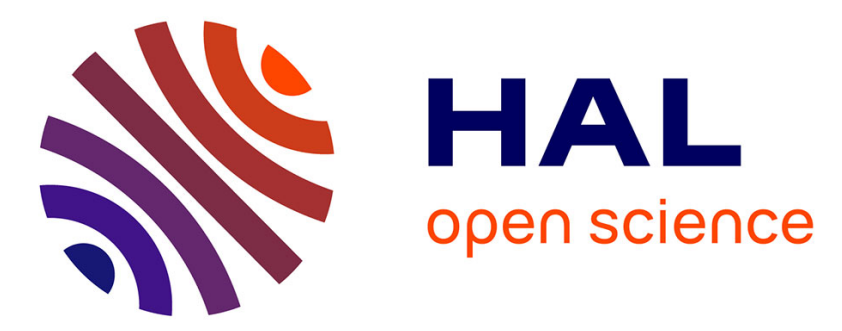

\title{
Diagnosis of injection-molded weld line in thermoplastic polymer by terahertz reflective imaging and scanning acoustic microscopy
}

Min Zhai, Esam Ahmed Mohamed, A. Locquet, G. Schneider, R. Kalmar, M. Fendler, N. Declercq, D.S. Citrin

\section{To cite this version:}

Min Zhai, Esam Ahmed Mohamed, A. Locquet, G. Schneider, R. Kalmar, et al.. Diagnosis of injection-molded weld line in thermoplastic polymer by terahertz reflective imaging and scanning acoustic microscopy. 2021 46th International Conference on Infrared, Millimeter and Terahertz Waves (IRMMW-THz), Aug 2021, Chengdu, China. pp.1-2, 10.1109/IRMMW-THz50926.2021.9567010 . hal-03419878

\section{HAL Id: hal-03419878 \\ https://hal.science/hal-03419878}

Submitted on 8 Nov 2021

HAL is a multi-disciplinary open access archive for the deposit and dissemination of scientific research documents, whether they are published or not. The documents may come from teaching and research institutions in France or abroad, or from public or private research centers.
L'archive ouverte pluridisciplinaire HAL, est destinée au dépôt et à la diffusion de documents scientifiques de niveau recherche, publiés ou non, émanant des établissements d'enseignement et de recherche français ou étrangers, des laboratoires publics ou privés. 


\title{
Diagnosis of injection-molded weld line in thermoplastic polymer by terahertz reflective imaging and scanning acoustic microscopy
}

\author{
Min Zhai, ${ }^{1,2}$ Esam T. Ahmed Mohamed, ${ }^{1,3}$ Alexandre Locquet, ${ }^{1,2}$ G. Schneider, ${ }^{4}$ R. Kalmar, ${ }^{4}$ M. Fendler, ${ }^{4}$ N. F. \\ Declercq, ${ }^{1,3}$ and D.S. Citrin ${ }^{1,2}$ \\ ${ }^{1}$ Georgia Tech-CNRS IRL2958, Georgia Tech Lorraine, 2 Rue Marconi, 57070 Metz, France \\ ${ }^{2}$ School of Electrical and Computer Engineering, Georgia Institute of Technology, Atlanta, Georgia, 30332-0250 USA \\ ${ }^{3}$ School of Mechanical Engineering. Georgia Institute of Technology, Atlanta, Georgia, 30332 USA \\ ${ }^{4}$ CEA Tech, 5 Rue Marconi, Bâtiment Austrasie, 57070 Metz, France
}

\begin{abstract}
Terahertz (THz) reflective imaging and scanning acoustic microscopy (SAM) were utilized to material characterization as well as quality control of the injection-molded thermoplastic electrical receptacle plate. $V$-notched weld lines that degrade the mechanical strength of injection-molded products significantly, are observed in both SAM and THz results. Microelastic heterogeneity resolved in acoustic micrograph validates the location-dependent birefringence observed in THz results.
\end{abstract}

\section{INTRODUCTION}

$\mathrm{W}$ eld lines in injection molding are introduced when two melt streams meet, degrading the mechanical properties at the weld. To date, the most common approach used to identify the location of weld lines is destructive mechanical testing. Owing to the nature of $\mathrm{THz}$ waves, it presents the potential of monitoring the quality of injection-molded thermoplastic products and characterizing the weld-line in a nondestructive and contactless manner.

\section{RESULTS}

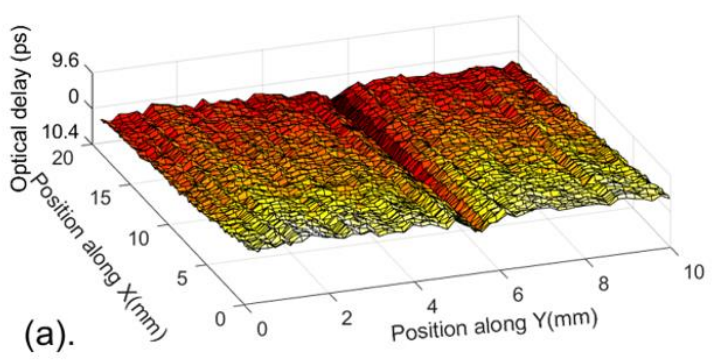

(b).

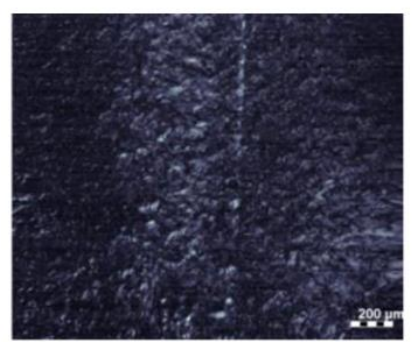

Fig. 1. (a). THz C-scans based on the peak reflected signal arrival time as the contrast mechanism. (b). SAM micrographs operating at center frequency $f=420$ $\mathrm{MHz}$.

The surface morphology of the injection-molded plastic samples was characterized using $\mathrm{THz}$ reflective imaging and SAM, shown in Fig. 1. V-shaped weld lines are observed in $\mathrm{THz}$ results. The width as well as depth of V-shaped notches were estimated, based on the arrival time of the echo reflected from the surface, to be $\sim 400 \mu \mathrm{m}$ and $\sim 10 \mu \mathrm{m}$, respectively. These values are close to SAM results.

Spatially dependent $\mathrm{THz}$ birefringence $\Delta n$ is observed in Fig. 2. We find that enhanced $\mathrm{THz}$ birefringence is localized around the weld line at $6 \mathrm{~mm}$ gradually decreasing on the length scale of $2 \mathrm{~mm}$ with distance from the weld. Moreover, a large discrepancy in the Rayleigh surface acoustic waves $\left(V_{\mathrm{R}}\right)$ found in SAM results, demonstrates the

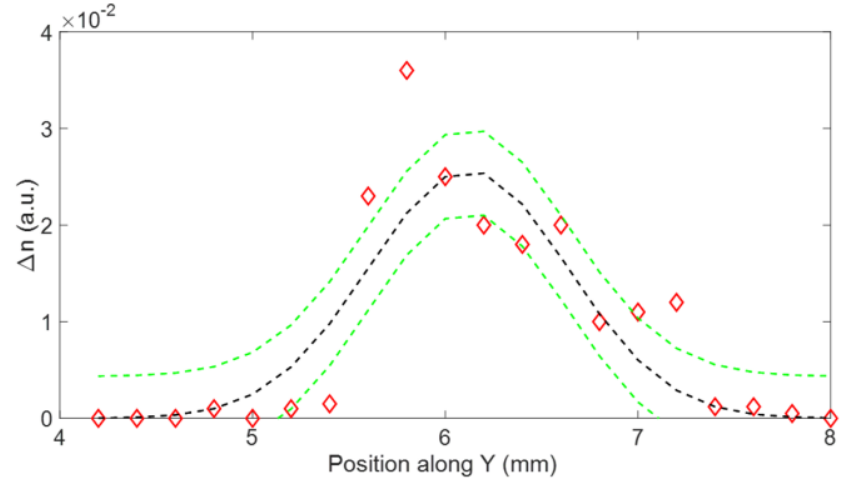

Fig. 2. Birefringence $\Delta n$ along section perpendicular to weld line.

variation in the micro-elastic properties between areas close to and distant from the weld lines. The spatial variation in birefringence and $V_{\mathrm{R}}$ indicates an anisotropic propagation of polarized $\mathrm{THz}$ and ultrasonic waves. Anisotropy at the weld might relate to the frozen-in molecular orientation and internal stress, which are more isotropic away from the weld. The locations of these features are consistent with injection conditions and mechanical failure under stress.

\section{SUMMARY}

In this work, $\mathrm{THz}$ reflective imaging and SAM are carried out to characterize the injection-mold weld lines in an acrylonitrile butadiene styrene (ABS) electrical receptacle plate. V-shaped notches are found in the surface morphology by THz imaging and SAM. An enhanced $\mathrm{THz}$ birefringence close to the weld lines indicates the anisotropy state due to the fountain flow, and the birefringence drops as locations move away from the weld lines with the material exhibiting more $\mathrm{THz}$ isotropy. THz results are also supported by SAM measurements and mechanical failure tests, demonstrating that $\mathrm{THz}$ techniques in conjunction with SAM, is capable of providing information for nondestructive reliability assessment and a characterization of local mechanical properties for injection-molded thermoplastic components.

\section{REFERENCES}

[1] M. Zhai, E.T. Mohamed, A. Locquet, G. Schneider, R. Kalmar, M. Fendler, N.F. Declercq, and D.S. Citrin, "Diagnosis of injection-molded weld lines in ABS thermoplastic by polarized terahertz reflective imaging," submitted to NDT\&E Int.

[2]. E.T. Mohamed, M. Zhai, G. Schneider, R. Kalmar, M. Fendler, A. Locquet, D.S. Citrin, and N.F. Declercq, "Scanning acoustic microscopy investigation of weld lines in injection-molded parts manufactured from industrial thermoplastic polymer," Micron, 138:102925, 2020.

[3]. G.H. Oh, J.H. Jeong, S.H. Park, and H.S. Kim, "Terahertz time-domain spectroscopy of weld line defects formed during an injection moulding process," Compos. Sci. Technol., 157:67-77, 2018. 